\title{
Qualitative analysis of safety factors of organizational and technological decisions made at the stage of development of project documentation
}

\author{
Azariy Lapidus ${ }^{1}$, Sergey Sinenko ${ }^{1}$, and Yana Shesterikova ${ }^{1, *}$ \\ ${ }^{1}$ Moscow State University of Civil Engineering (National Research University), Moscow, Russia
}

\begin{abstract}
Many factors influence what organizational and technological decisions will be made to ensure the safety of buildings and structures. The authors considered factors reflecting their full characteristics. Based on the regulatory documentation used in the design of buildings and structures for the section of design documentation "Structural and space-planning decisions", the types of safety that are influenced by the design decisions are determined, factors for each type of safety are determined, and safety factors are ranked by importance.
\end{abstract}

\section{Introduction}

The technical level of construction is influenced by many factors that significantly affect it. The selection of rational, economically feasible solutions in the development of organizational and technological documentation should be based on a comparison of options, taking into account all factors affecting the construction project.

Currently, there is a growing trend in the number of emergencies, which makes builders and designers more often think about the safety of buildings and structures.

In view of the current situation, on December 30, 2009 Federal Law of the Russian Federation N 384 "Technical Regulations on the Safety of Buildings and Structures" was adopted in accordance with which the requirements of mechanical, emergency, fire, operational and environmental safety are established.

The problem of assessing the influence of factors, as well as the influence of a combination of factors determining the choice of organizational and technological solutions, is currently relevant.

\section{Materials and methods}

Qualitative analysis - a set of methods and techniques used to detect factors that make up the analyzed object. This study identifies safety factors that influence the choice of organizational and technological solutions for the 4th section of the project "Constructive

\footnotetext{
*Corresponding author: shesterikova.jana@yandex.ru
} 
and space-planning decisions", and also classifies the factors according to the degree of influence on organizational and technological decisions.

To determine the degree of influence, a gradation of factors was made by three points:

1-has a low impact on decisions made,

2-has an average impact on decisions made,

3-has a high impact on decisions;

The classification of factors for buildings and structures for various purposes is different, it is necessary to take into account the features of individual buildings and structures.

For a qualitative analysis of safety factors, for each section of the design documentation, the types of safety must be defined. In section 4 of the design documentation, the following types of safety should be considered:

- mechanical;

- emergency;

- $\quad$ fire department;

- operational.

Further, factors are determined for each type of security, and they are ranked according to their degree of influence.

The level of detail of the study is determined by the tasks facing analysts.

Factors are determined by express analysis methods. Express analysis is a brief technical and economic study that gives a general idea of a building object, establishes its "weak" features and forms directions for their expanded study. A similar analysis is carried out by specialists of the building organization or external users on the developed project, its construction and operation (life cycle). The methods and techniques were used:

- horizontal (time) analysis, which makes it possible to assess the dynamics of changes in characteristics over a specific period of time. Conduct it by comparing and then studying their transformations;

- $\quad$ vertical (structural) analysis, which consists in determining the specific gravity of the causes of negative changes;

- calculation of coefficients establishing interdependencies between changes in individual values, their dynamics and impact on the state of a construction organization.

\section{Results}

\subsection{Factors affecting mechanical safety}

\subsubsection{Factor "Significance of the structure"}

There are three classes of structures: KS-1, KS-2, KS-3, depending on their significance [1, 2]. Table 1 is a ranking of the significance of the factor depending on the class of construction.

\subsubsection{Factor "Engineering and geological conditions"}

Basic provisions the degree of influence of this factor is determined in accordance with the category of complexity of engineering and geological conditions [3]. Three categories of complexity of engineering and geological conditions are distinguished.

Category I (simple), according to which the site (site) is within the same geomorphological element, in the sphere of interaction of buildings and structures, no more than two layers of different lithology are represented, of an insignificant degree of 
heterogeneity in terms of soil properties. Groundwater is absent or there is one mature groundwater horizon with a uniform chemical composition. Geological and engineeringgeological processes that negatively affect the conditions of construction and operation of buildings and structures are absent. There are no specific soils in the field of interaction of buildings and structures with the geological environment. Man-made impacts and changes in the developed territories are insignificant and may not be taken into account in engineering-geological surveys and design.

Category II (medium complexity), according to which the site (site) is located within several geomorphological elements of the same genesis, in the sphere of interaction of buildings and structures with the geological environment, no more than four layers of different lithology are present, lying obliquely or with pinching out. There are two or more mature groundwater horizons, sometimes with a heterogeneous chemical composition or with pressure and containing pollution. Geological and engineering-geological processes that adversely affect the conditions of construction and operation of buildings and structures, specific soils, as well as technological impacts and changes in developed territories are of limited distribution and (or) do not significantly affect the choice of design solutions, construction and operation of facilities.

Category III (complex), according to which the site (site) is located within several geomorphological elements of different genesis, the surface is strongly dissected. In the field of interaction of buildings and structures with the geological environment, more than four layers of different lithology are represented, lenticular bedding of layers, a significant degree of heterogeneity in terms of soil properties, varying in plan or in depth. Groundwater horizons are not sustained along strike and thickness, with heterogeneous chemical composition or various pollution, in places there is a complex alternation of aquifers and water-resistant rocks, groundwater pressure and their hydraulic connection vary along strike. Geological and engineering-geological processes that adversely affect the conditions of construction and operation of buildings and structures, as well as specific soils are widespread and (or) have a decisive influence on the choice of design solutions, construction and operation of facilities. Man-made impacts and changes in the developed territories have a significant impact on the choice of design solutions and complicate the production of engineering and geological surveys in terms of increasing their composition and scope of work.

It should be noted that soils of a less complex category, which have at least one characteristic from a more complex category, belong to a more complex category.

\subsubsection{Factor "Geometric characteristics of the object"}

This factor is determined by the various geometric parameters of the building or structure. The geometric parameters that have the greatest impact on the mechanical safety of buildings and structures are highlighted and ranked according to the degree of influence: the height of buildings and structures, the area of buildings and structures, the depth of the foundation, the magnitude of the span between vertical elements.

\subsubsection{Factor "Effective load"}

Depending on the duration of the loads, it is necessary to distinguish between permanent and temporary (long, short-term, special) loads [4].

Constant loads in this study are taken into account by the geometric characteristics of the object.

Payloads (long and short-term, with the exception of climatic loads) for civil buildings and structures are represented by loads from non-load-bearing structures, equipment, 
people, cars, etc. In this study, the gradation of the load values was performed depending on the degree of their excess over the existing ones: by $10 \%$, by $20 \%$, by $40 \%$.

\subsubsection{Climatic loads}

Buildings and structures are affected by climatic phenomena: temperature, humidity, climatic precipitation, wind, etc. Parameters that have the greatest impact on mechanical safety: the weight of the snow cover and wind pressure are highlighted. The territory of the Russian Federation is divided into 8 regions by weight of snow cover, to set the score for the degree of influence, the regions were combined into groups I-III, IV-VI, VII-VIII, with the corresponding snow cover weight from 0 to $1.8 \mathrm{kPA}$, from 1.8 up to $4 \mathrm{kPA}$, over $4 \mathrm{kPA}$. According to wind pressure, the territory of the Russian Federation is also divided into 7 regions, to set the point of degree of influence, the regions were combined into groups I-II, III-V, VI-VII, with the corresponding standard value of wind pressure w0 to $0.3 \mathrm{kPa}$, from 0.3 up to $0.6 \mathrm{kPa}$, over $0.6 \mathrm{kPa}$.

\subsubsection{Special loads}

This factor affects mechanical safety during emergency and emergency situations and will be considered in the classification of factors affecting the emergency safety of a building.

Factors affecting the mechanical safety of buildings and structures are presented in table 1.

Table 1. Factors affecting the mechanical safety of buildings and structures.

\begin{tabular}{|c|c|c|c|}
\hline Type of security & Safety factor & \multicolumn{2}{|c|}{ The significance of the factor } \\
\hline \multirow{26}{*}{$\begin{array}{l}\text { Mechanical } \\
\text { safety }\end{array}$} & \multirow{4}{*}{$\begin{array}{l}\text { Construction } \\
\text { significance }\end{array}$} & Class of construction & Degree of significance \\
\hline & & KS-1 & 1 \\
\hline & & KS-2 & 2 \\
\hline & & KS-3 & 3 \\
\hline & Engineering & $\begin{array}{l}\text { Category of complexity of } \\
\text { engineering and geological } \\
\text { conditions }\end{array}$ & Degree of significance \\
\hline & and geological & $\mathrm{I}$ & 1 \\
\hline & & II & 2 \\
\hline & & III & 3 \\
\hline & & Foundation depth & Degree of significance \\
\hline & & $0-3 \mathrm{~m}$ & 1 \\
\hline & & $3-10 \mathrm{~m}$ & 2 \\
\hline & & $>10 \mathrm{~m}$ & 3 \\
\hline & & Building height & Degree of significance \\
\hline & & $0-30 \mathrm{~m}$ & 1 \\
\hline & & $30-75 \mathrm{~m}$ & 2 \\
\hline & Geometric & $>75 \mathrm{~m}$ & 3 \\
\hline & characteristics & Building area & Degree of significance \\
\hline & & $<1000 \mathrm{~m}^{2}$ & 1 \\
\hline & & $1000-2000 \mathrm{~m}^{2}$ & 2 \\
\hline & & $>2000 \mathrm{~m}^{2}$ & 3 \\
\hline & & Building span & Degree of significance \\
\hline & & $<4 \mathrm{~m}$ & 1 \\
\hline & & $4-8 \mathrm{~m}$ & 2 \\
\hline & & $>8 \mathrm{~m}$ & 3 \\
\hline & Ceurent lond & Excessive load & Degree of significance \\
\hline & Current load & $10 \%$ & 1 \\
\hline
\end{tabular}




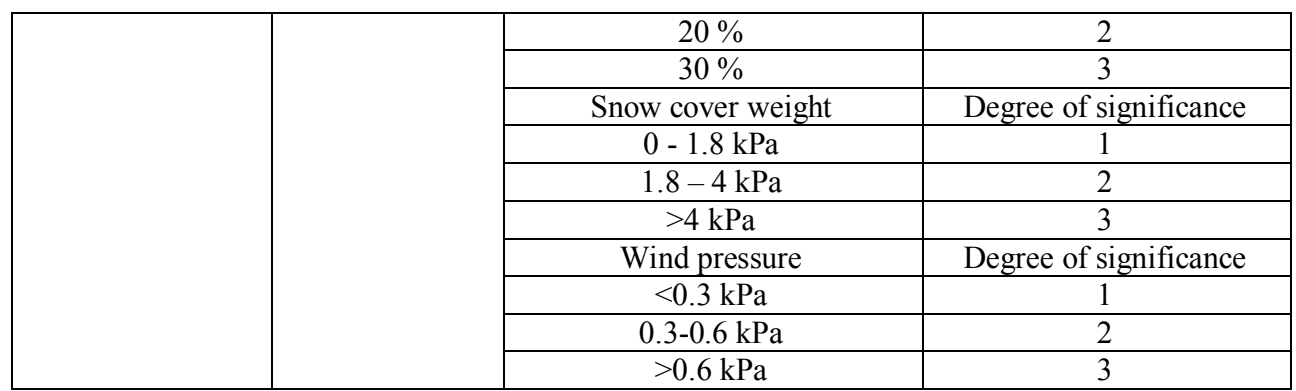

\subsection{Factors affecting emergency safety}

\subsubsection{Factor "Special loads"}

Special loads should include: a) seismic effects; b) explosive effects; c) loads caused by sudden violations of the process, temporary malfunction or breakdown of equipment; $d$ ) impacts caused by deformations of the base, accompanied by a radical change in the structure of the soil (for example, when soaking subsidence soils) or its subsidence in areas of mine workings and in karst bases; e) loads due to fire; e) loads from collisions of vehicles with parts of the structure.

In this study, the above loads are divided into two factors: seismic impact and other special loads.

Seismic effects. The design of structures and foundations of $\mathrm{ZiS}$ designed for construction in seismic areas should be performed on the main and special load combinations taking into account seismic effects corresponding to the OSR-97 General Seismic Zoning maps [5]. The degree of influence of this factor was ranked depending on the calculated seismic activity in points: up to 6 points, 7-8 points, 9 or more points;

Other loads. During construction and operation, ZIS can be affected by various loads due to the conditions of a particular area, geotechnical conditions, etc. Different types of such loads have different meanings and are applied to different building structures. The classification of this factor is made depending on the value of the loads: up to $5 \mathrm{kN}, 5-10$ $\mathrm{kN}$, over $10 \mathrm{kN}$. 2.

Factors affecting the emergency safety of buildings and structures are presented in table

Table 2. Factors affecting the emergency safety of buildings and structures.

\begin{tabular}{|l|c|c|c|}
\hline Type of security & Safety factor & \multicolumn{2}{|c|}{ The significance of the factor } \\
\hline \multirow{4}{*}{ Emergency safety } & Seismic area & Degree of significance \\
\cline { 3 - 4 } & \multirow{4}{*}{ Special loads } & $<6$ points & 1 \\
\cline { 3 - 4 } & & $7-8$ & 2 \\
\cline { 3 - 4 } & & $9-10$ & 3 \\
\cline { 3 - 4 } & & Other non-design loads & Degree of significance \\
\cline { 3 - 4 } & & $<5 \mathrm{kN}$ & 1 \\
\cline { 3 - 4 } & & $5-10 \mathrm{kN}$ & 2 \\
\cline { 3 - 4 } & & $>10 \mathrm{kN}$ & 3 \\
\hline
\end{tabular}

\subsection{Factors affecting fire safety}

\subsubsection{Factor "Fire Resistance ZIS"}


This factor is determined in accordance with the degree of fire resistance of buildings and structures [6].

Buildings, structures, structures and fire compartments according to the degree of fire resistance are divided into buildings, structures, structures and fire compartments of I, II, III, IV and V degrees of fire resistance. The degree of fire resistance of buildings, structures, structures and fire compartments should be established depending on their number of storeys, class of functional fire hazard, fire compartment area and fire hazard of technological processes occurring in them.

The degrees of fire resistance of buildings are assigned [7, 8].

Fire resistance class I includes class $\mathrm{ZiS}$ of the structural fire hazard class $\mathrm{C} 0$, with the highest permissible height of $75 \mathrm{~m}$ and the largest permissible area of the fire compartment of $2500 \mathrm{~m} 2$.

Fire protection class II includes ZiS of the class of structural fire hazard $\mathrm{C} 0$ and $\mathrm{C} 1$, with the highest permissible height from 28 to $50 \mathrm{~m}$ and the largest permissible area of the fire compartment from 2200 to $2500 \mathrm{~m} 2$.

The III degree of fire resistance includes ZiS of the class of constructive fire hazard C0 and $\mathrm{C} 1$, with the highest permissible height from 15 to $28 \mathrm{~m}$ and the largest permissible area of the fire compartment up to $1800 \mathrm{~m} 2$.

The 4th degree of fire resistance includes $\mathrm{ZiS}$ of the class of constructive fire hazard $\mathrm{C} 0$, $\mathrm{C} 1$ and $\mathrm{C} 2$, with the highest permissible height from 3 to $5 \mathrm{~m}$ and the largest allowable fire compartment area from 900 to $1400 \mathrm{~m} 2$ depending on the class of constructive fire hazard of the building.

The $\mathrm{V}$ degree of fire resistance includes $\mathrm{ZiS}$ with the highest permissible height of up to $5 \mathrm{~m}$ and the largest permissible area of the fire compartment from 500 to $800 \mathrm{~m} 2$ depending on the height of the building.

According to SNiP 21-01-97 * "Fire safety of buildings and structures", depending on the degree of fire resistance of a building or structure, fire resistance limits of the main structures are assigned (table 3 ), which should be provided when choosing organizational and technological solutions.

Table 3. Fire resistance limits of the main structures.

\begin{tabular}{|c|c|c|c|c|c|c|c|}
\hline \multirow{3}{*}{\begin{tabular}{|c|} 
The degree \\
ire \\
resistance \\
the \\
building
\end{tabular}} & \multicolumn{7}{|c|}{ Fire resistance of building structures no less } \\
\hline & \multirow{2}{*}{$\begin{array}{l}\text { Bearing } \\
\text { element } \\
\text { of the } \\
\text { building }\end{array}$} & \multirow{2}{*}{$\begin{array}{c}\text { External } \\
\text { Curtain } \\
\text { Walls }\end{array}$} & \multirow{2}{*}{$\begin{array}{c}\text { Overlappi } \\
\text { ng } \\
\text { between } \\
\text { floor }\end{array}$} & \multicolumn{2}{|c|}{$\begin{array}{l}\text { Elements of non- } \\
\text { covering coatings }\end{array}$} & \multicolumn{2}{|c|}{ Stairwells } \\
\hline & & & & Flooring & $\begin{array}{l}\text { Farms, } \\
\text { beams }\end{array}$ & $\begin{array}{c}\text { Interior } \\
\text { walls }\end{array}$ & $\begin{array}{c}\text { Marches and } \\
\text { stairways }\end{array}$ \\
\hline I & R 120 & E 30 & REI 60 & RE 30 & RE 30 & $\begin{array}{l}\text { REI } \\
120\end{array}$ & $\mathrm{R} 60$ \\
\hline II & R 90 & E 15 & REI 45 & RE 15 & RE 15 & REI 90 & R 60 \\
\hline III & $\mathrm{R} 45$ & E 15 & REI 45 & RE 15 & RE 15 & REI 60 & $\mathrm{R} 45$ \\
\hline IV & R 15 & E 15 & REI 15 & RE 15 & RE 15 & REI 45 & R 15 \\
\hline $\mathrm{V}$ & $\begin{array}{c}\text { Not } \\
\text { standard } \\
\text { ized }\end{array}$ & $\begin{array}{c}\text { Not } \\
\text { standard } \\
\text { ized }\end{array}$ & $\begin{array}{c}\text { Not } \\
\text { standardiz } \\
\text { ed }\end{array}$ & $\begin{array}{c}\text { Not } \\
\text { standardi } \\
\text { zed }\end{array}$ & $\begin{array}{c}\text { Not } \\
\text { standard } \\
\text { ized }\end{array}$ & $\begin{array}{c}\text { Not } \\
\text { standar } \\
\text { dized }\end{array}$ & $\begin{array}{c}\text { Not } \\
\text { standardized }\end{array}$ \\
\hline
\end{tabular}

Factors affecting the fire safety of buildings and structures are presented in table 4 .

Table 4. Factors affecting the fire safety of buildings and structures.

\begin{tabular}{|c|c|c|c|}
\hline Type of security & Safety factor & \multicolumn{2}{|c|}{ The significance of the factor } \\
\hline \multirow{3}{*}{ Fire safety } & \multirow{3}{*}{ Fire resistance ZIS } & Fire rating ZiS & Degree of significance \\
\cline { 3 - 4 } & & III-IV & 1 \\
\cline { 3 - 4 } & & II & 2 \\
\cline { 3 - 4 } & & I & 3 \\
\hline
\end{tabular}




\subsection{Factor "Durability"}

The necessary measures to ensure the durability of the structures and foundations of buildings and structures, taking into account the specific operating conditions of the designed objects, as well as the estimated service life, must be determined by the general designer in agreement with the customer. Distinguish buildings and structures with an approximate service life [2]:

-10 years for temporary buildings and structures,

-not less than 25 years- for structures operated in highly aggressive environments,

-at least 50 years - for buildings and structures of mass construction under normal operating conditions, -100 years or more - for unique buildings and structures.

For the purposes of our study, we divide the service life into 3 categories: up to 50 years, from 50 to 100 years, over 100 years. 5 .

Factors affecting the operational safety of buildings and structures are presented in table

Table 5. Factors affecting the operational safety of buildings and structures.

\begin{tabular}{|c|c|c|c|}
\hline Type of security & Safety factor & \multicolumn{2}{|c|}{ The significance of the factor } \\
\hline \multirow{4}{*}{ Operational safety } & \multirow{4}{*}{ Durability } & Life time & Degree of significance \\
\cline { 3 - 4 } & & $<50$ years & 1 \\
\cline { 3 - 4 } & & $50-100$ years & 2 \\
\cline { 3 - 4 } & $>100$ years & 3 \\
\hline
\end{tabular}

\section{Discussion}

Based on the regulatory documentation used in the design of buildings and structures, for the 4th section of the design documentation "Structural and space-planning decisions", the types of security that are influenced by the design decisions are determined, the factors for each type of safety are determined, and the safety factors are ranked according to the degree of importance.

This made it possible to choose rational, economically feasible solutions when developing a project for the organization of construction (PIC), in particular, a schedule, the basic methods of construction and installation work, the need for material, technical, labor, and other resources, etc.

\section{References}

1. Federal Law of the Russian Federation N 384 "Technical Regulations on the Safety of Buildings and Structures"

2. GOST R 54257-2010 "Reliability of building structures and foundations. Main provisions and requirements"

3. SP 47.13330.2012 Engineering surveys for construction. Key points

4. SP 20.13330.2011 Load and impact

5. SP 14.13330.2011 Construction in seismic areas

6. Federal Law N 123 "Technical Regulations on Fire Safety Requirements"

7. SP 54.13330.2011 Residential multi-apartment buildings

8. SP 118.13330.2012 Public buildings and structures

9. A.A. Volkov, E.A. Serova, Internet bulletin VolgGASU. Political 3, (2012) 
10. STO NOSTROY 26.54-2011 "Monolithic, concrete and reinforced concrete structures. Technical requirements for the production of work, the rules and methods of control "M., 2011

11. A.A. Lapidus, L.P. Demidov, Vestnik MGSU 4, (2014)

12. A.A. Lapidus. Y.V. Shesterikova, Modern science and innovations 3, 74-80 (2017)

13. A. Lapidus, I. Abramov, E3S Web of Conferences, 03066 (2018)

14. L.A. SaydayevKh, Organizational and managerial modeling of a comprehensive assessment of the construction companies performance result. Candidate dissertation, Moscow, (2012)

15. D.V. Topchy, Organizational and technological modeling of construction and installation works with a comprehensive assessment of the effectiveness of the conversion of industrial facilities. Candidate dissertation, Moscow (2015)

16. T.M. Froese, Automation in Construction 19(5), 531-538 (2010) 